\title{
Influence of Teachers' Assessment Competency on Pupils' Academic Achievement in Kisumu County
}

\author{
Nyanjom, Anolyce Omondi ${ }^{1 *}$, Dr. YAMBO, J. M. O. $\mathrm{PhD}^{2}$, Dr. Ongunya, Raphael, O. PhD ${ }^{3}$ \\ ${ }^{1}$ Department of Curriculum and Instruction Kisii University \\ ${ }^{2}$ Department of Educational Administration, Planning and Economics Kisii University \\ ${ }^{3}$ Dept. of Curriculum and Instruction Masinde Muliro University of Science and Technology
}

\begin{abstract}
DOI: $10.36348 /$ jaep.2020.v04i11.009 $\quad$ | Received: 06.11.2020 | Accepted: 18.11 .2020 | Published: 23.11 .2020
*Corresponding author: Nyanjom, Anolyce Omondi
\end{abstract}

\section{Abstract}

Purpose of the study was to establish the influence of teachers' assessment competency on pupils' academic achievement in Kisumu County. The study employed survey research design. The study was conceptualized on principles of highquality teaching and learning. Study Population comprised 3290 teachers, 658 head teachers, 7 assurance officers and 7 directors. Saunders, Lewis and Thornhill table was used to select sample of 294 teachers and 203 head teachers. Study sample were selected by stratified, random and purposive sampling. Samples selected comprised 294 teachers, 203 head teachers, 7 assurance officers and 7 directors. Informed consent, confidentiality of respondents were observed and data collected at work place. All sources were cited to avoid plagiarism Data was collected using questionnaire, interview schedule and observation checklist. Validity was ensured by comprehensively including all the study variables after which they were presented for assessment to the specialists in Curriculum and Instruction in Kisii University. Reliability of the instruments was determined by test-retest method. Correlation coefficient of teachers' questionnaire, Head teachers' questionnaire, QASOs interview schedule, ADDTMs interview schedule and teachers' observation checklist yielded $0.75,0.71,0.73,0.74$ and 0.77 respectively. Level of significance was set at 5\%. Data was analyzed using quantitative and qualitative techniques. Quantitative data was sorted, coded and processed using SPSS version 20 to generate frequencies and percentages. Hypotheses were tested using Pearson's Product-Moment Correlations and Multiple Linear Regressions to establish presence or absence of correlations and association. Qualitative data were sorted into themes and sub-themes, analyzed in an on-going process then reported in prose. Teaching skills and assessment competencies had statistically significant relationship with pupils' academic achievement at $(0.125)$, p-value $(0.027)<$ 0.05 and $(0.121)$, p-value $(0.033)<0.05$ respectively. It was recommended that teachers' competencies be enhanced through in-service courses; review tests and measurements in professional studies offered in colleges.

Keywords: Teachers, knowledge, competency, academic, achievement, Kenya.

Copyright $\odot$ 2020 The Author(s): This is an open-access article distributed under the terms of the Creative Commons Attribution 4.0 International License (CC BY-NC 4.0) which permits unrestricted use, distribution, and reproduction in any medium for non-commercial use provided the original author and source are credited.

\section{INTRODUCTION}

In United States of America (U.S.A), Lanier [1] observes that pupils are not consumers of knowledge but creators, thus teachers are facilitators of learning, teachers need to set learning standards and assess how they are met. Teachers also need knowledge and professional values competencies. Moreover, Brick and Williams [2] contends that in order to transform U.S.A learning landscape there is need for setting teacher competency standards. This imply teacher competency framework. Lanier [1] has not addressed the extent to which teacher competency influences pupils' academic achievement. This was focus of the study. Report by University of Mexico [3] revealed that demand for highly qualified teachers to address academic achievements of students has led to teachers' competency framework for licensing of teachers in New Mexico. This implies that teacher quality has influence on pupils' academic achievement. Thus, need to find out influence of teachers' competency on pupils' academic achievement. Research conducted by Department of Education and Training in Australia confirmed teacher competency as one of the most important factor-influencing student's academic achievement [4]. Apart from identifying teacher competency as one of the most important factors influencing student's academic achievement, the study did not explore the extent to which each competency influenced pupil's academic achievement. This study filled this gap by exploring the correlations between these competencies and pupils academic achievement. 
General Teaching Council of Northern Ireland [G.T.C.N.I], [5] outlined teacher professional competencies as professional value and practice; professional knowledge and understanding; and professional skills and application. The council opines that teachers' competencies be looked at holistically. This study embraced a holistic approach of teachers' competencies.

Developing countries are not left behind in development of teachers' competency standards; they have embarked on development of teacher competency framework (T.C.F). In India, teachers' professional competencies are classified under instruction competencies, organization competencies and evaluative competencies. Recent research by Kulshrestha and Pandey [6] in India revealed that there is direct link in the field of education between teacher competencies and pupils academic achievement. In study by Goh [7] it showed that in Malaysia teacher competencies begin during teacher candidate stage and continue throughout when beginning teachers are assessed to become confirmed staff of the teaching profession. Malaysia economic transformation has made teacher quality in the education system a priority [8]. Research by Abdul and Abdul [9] in primary schools in Johar Bahru of Malaysia revealed that all teachers are competent and there is a significant relationship between teacher competency and pupil academic achievement. However, subject content knowledge, teaching skills and classroom management were found to require improvement to build image as competent teachers. Research by Abdul and Abdul [9], Kulshrestha and Pandey [6] did not explicitly explore level of teacher competencies influence on pupils' academic achievement; this was focus of the current study.

Due to importance attached to teacher competency worldwide, Uganda has developed competency profile for primary school teachers [10]. The profile is to help stakeholders direct their efforts appropriately in their quest for teacher improvement. Research by Nzilano [11], on teacher competencies of pre-service teachers on teaching practice revealed that there are limited competencies among pre-service teachers in Tanzania. This research failed to recognize manifest competencies. The present study assessed manifest competencies of practicing teachers. Mosha [12] observed that teachers' knowledge competency was a factor affecting students' academic achievement in English language in Zanzibar rural and urban secondary schools. Poor academic achievement of students in rural areas was majorly attributed to presence of untrained, under qualified and incompetent teachers. This study did not explore assessment and professional teacher competences. Further, the study did not address statistical significance of these factors. The current study explored teachers' knowledge competency and determined its statistical significance on pupils' academic achievement.

Kisumu County has seven sub-counties. In this study, the sub-counties were coded K1 to K7. The County had recorded 255.92, 264.91, 262.20, 286.39 and 255.92 mean scores out of 500 possible marks in the last five years in Kenya Certificate of Primary Education (KCPE). Sub-counties K7, K6 and K5 have been registering below 260 mean score with $\mathrm{K} 7$ trailing at 243.32, 247.58 and 249.22 for the previous three years [13]. The KCPE mean scores for the last five years in the county are not encouraging. In addition, the wide disparity in mean score between $\mathrm{K} 1$ and $\mathrm{K} 7$ is a cause to worry. Teacher competency framework is in place and research from other countries on teachers' competencies and pupil's academic achievement show that there is a positive correlation. However, studies by Goodman, Arbona, and Dominguez de Rameriz [14] conclude that the competency or courses which matter most in teacher education remains an open question. In addition, different researchers such as Kumar [15], Rakido, Kiplagat and Nyongesa [16], Sultan and Shafi [17] have studied teachers' knowledge, assessment, teaching skills and professional values competencies separately and in isolation. Thus, specific contribution of each competency to pupils' academic achievement remains unclear. This study addressed the four teachers' competencies and established their relationships with pupils' academic achievements in primary schools in the County, as KCPE performance in the county is not encouraging. Trend of KCPE performance in the county is shown in Table 1.

Table-1: KCPE Trend in Kisumu County between 20134and 2019

\begin{tabular}{|r|l|l|l|l|l|l|l|}
\hline SUB-COUNTY & MAX. KCPE SCORE & & \multicolumn{5}{|c|}{ MEAN SCORES } \\
\hline & & $\mathbf{2 0 1 9}$ & $\mathbf{2 0 1 8}$ & $\mathbf{2 0 1 7}$ & $\mathbf{2 0 1 6}$ & $\mathbf{2 0 1 5}$ & $\mathbf{2 0 1 4}$ \\
\hline K1 & 500 & 294.76 & 273.09 & 303.37 & 310.60 & 297.06 & 299.04 \\
\hline K2 & 500 & 260.96 & 260.15 & 263.81 & 263.89 & 269.35 & 271.45 \\
\hline K3 & 500 & 257.37 & 261.43 & 269.18 & 260.31 & 264.38 & 265.67 \\
\hline K4 & 500 & 257.26 & 257.48 & 258.46 & 250.92 & 263.03 & 261.57 \\
\hline K5 & 500 & 252.91 & 254.14 & 258.86 & 250.03 & 254.43 & 256.2 \\
\hline K6 & 500 & 247.61 & 203.99 & 253.13 & 256.46 & 247.47 & 251.52 \\
\hline K7 & 500 & 243.22 & 203.15 & 247.58 & 243.32 & 251.06 & 249.22 \\
\hline COUNTY & & & $\mathbf{2 5 5 . 9 2}$ & $\mathbf{2 6 4 . 9 1}$ & $\mathbf{2 6 2 . 2 2}$ & $\mathbf{2 6 4 . 1 1}$ & $\mathbf{2 6 4 . 9 5}$ \\
\hline
\end{tabular}

Source: County Director Education, Kisumu, 2019 
Kisumu County has seven sub-counties, these have been coded K1 to K7. From Table 1.1, Kisumu County KCPE mean score for the previous three years has been below 265. Sub-county K1 has consistently recorded a mean score of between 310.06 and 273.09 for the last five years while mean score for sub-county K7 has been below 250 apart from 2015 when it registered a mean score of 283.39. The difference in mean score between sub-counties $\mathrm{K} 1$ and $\mathrm{K} 7$ has been over 30 for the previous three years. This study focused on the cause of this remarkable difference in mean score.

\section{Statement of the Problem}

In pursuit of pupils' academic achievement, teachers' professional competencies are of great importance. In an attempt to help teachers improve in their competencies hence performance, Ministry of Education Science and Technology (MOEST) has put in place competency framework for primary school teachers. Kisumu County education office has been organizing insets through workshops and seminars for teachers. In some sub-counties in Kisumu County, parents and other stakeholders have been motivating teachers and pupils through field trips. Despite these efforts, performance in KCPE in Kisumu County is still not encouraging and there is a wide disparity in KCPE performance among the sub-counties as shown in Table 1.1. Kisumu County has professionally qualified teachers who should have the required competencies to propel pupils' academic achievement. Yet, pupils' academic achievement in some sub-counties is still below average. Thus, it was important to explore teachers' competencies influence on pupils' academic achievement in Kisumu County.

\section{Teachers Assessment Competency and Pupils' Academic Achievement}

Assessment in education institution involves identifying, gathering and interpreting information about learners achievement to establish the extent to which the learner has acquired the expected competencies with a view to informing interventions for further acquisition and mastery of the expected competencies and provide evince of satisfactory [18]. Assessment helps to diagnose and monitor the progress of a learner, and provide feedback to learners, parents, teachers and curriculum designers. This helps the teacher and curriculum designers to plan learning in terms of what the learner needs. Thus, a trained teachers is expected to have been exposed to assessment knowledge during pre-service training.

Teachers' competencies have different level of impact on students' academic achievement. Keyworth et al. [19] presented a paper on teacher competency that have greatest impact on student achievement at the proceedings of Wing Institute fifth annual summit on evidence education at crossroad, the state of teacher preparation in Oakland. They contend that there is abundant knowledge-base to inform us that in schools teachers play the critical role in student learning and achievement. Finding of this study indicate that teachers' assessment competency is a key to yielding great results. Teachers' assessment competency was referred to as effective ongoing assessment normally known as formative assessment in education literature Teachers' assessment competency comprised assessment tool, data display and data analysis. This should improve teachers practice and enhance pupils' academic achievement. Research carried out by Hattie [20] pointed out that feedback in assessment is the single most powerful instrument for improving pupils' academic achievement. Hattie contends that formative assessment is at the top of intervention for school improvement. The current study was set out to establish the influence of teachers' assessment competency on pupils' academic achievement to ascertain the school of thought that teachers' assessment competency is at the top of intervention for school improvement. In addition, the current study compared teachers' competencies influence on pupils' academic achievement to establish which one had the greatest influence.

In assessment of learning there are formative and summative assessments. In countries where curriculum is centralized, summative assessment is conducted by a central examination body. In United States of America (U.S.A), there is formative classroom assessment and large-scale assessment [21]. Large-scale assessment is aligned to state standards. However, alignment of formative assessment to state standards is rare. This is worsened by the fact that in America state law permit students to opt out of examination. This was witnessed recently in California High School where $75 \%$ of students in junior class opted out of California Assessment of Students Performance and Progress Examination. The principal, C. J. Foss reversed her decision to punish the students because Pacific Justice Institute in a letter, threatened lawsuit claiming that the principal was taking action against students who were exercising their rights [22]. Teachers' assessment competency problem is traced to lack of exposure to assessment knowledge and skills in most of pre-service training programmes for educators. Most educators begin their career with bumpy exposure to the fundamental of assessment or worse. At present, most states do not recognize coursework in assessment as a condition for licensing. It is well documented that most educators currently lack preparation skills in assessment. Assessment competencies include choosing and developing assessment methods, using assessment results in decision making and communicating to students and other stakeholders, recognizing unethical assessment practices [23]. Gregory [24] rightfully observed that there was a serious problem with educators as they lacked fundamental skills of assessment despite the set standards as this was not provided in the pre-service training; further, it was not recognized as a condition for licensing. However, he 
failed to suggest the way forward. The current study focused on teachers' assessment competency and the way forward.

In some countries, teachers lack adequate knowledge of assessment. This has been attributed to lack of proper training in educational measurements techniques in pre-service training. Study by Gullicson [25] revealed that a substantial proportion of teachers in Canada had little or no formal training in educational measurements techniques and many of those who had such training found it of little relevance to their classroom assessment activities. This was especially true for elementary school teachers as they heavily relied on observation and other non-test means of assessment and evaluation. This concurred with the recommendation of the task force for education excellence released the previous year, which recommended allowing people of other trades and professions to get teaching certificates without getting an educational degree [26]. Gullicson observed that Canadian teachers especially at elementary level had little training in educational measurement techniques and were concerned with those inadequacies. However, how those inadequacies were to be eradicated was not suggested. The present study attempted to align assessment competencies to international and national contemporary practice and recommended the way forward.

In order for education standards to be uniform in a country, summative assessment should be carried out by a central national examination body. In Singapore, Singapore Primary School Leaving Examination (PSLE) is a national examination administered by Ministry of Education and taken by all students near the end of their sixth year before they move to secondary school. Students are tested in English proficiency, respective mother tongue, mathematics and science. Students answer multiple choices by shading their responses on a standardized optical answer sheet [27]. This is similar to Kenya case. In the year 2007, complaints were made about PSLE papers being out of syllabus and too challenging. Ministry of Education responded by stating that difficult questions were meant to filter the average and below average students. In the subsequent two years, the same happened culminating into most students being unable to finish mathematics paper. Previously, in the year 2005 Mathematics paper question number 13 had no definite method of working out an answer. It was mathematically inconsistent as different methods yielded different answers. The Singapore Examination and Assessment Board awarded students free marks for this question [28]. The implication was that primary school teachers in Singapore were not conversant with primary school syllabus and they were not making adequate use of assessment competency. In a measurement instrument for examination, test items should be constructed and balanced taking cognizance of Table of specification which is test blue print showing whether the items will be testing knowledge, comprehensive, application, analysis, synthesis or evaluation levels of cognitive domain. The current study explored practicing teachers' assessment competency and found out areas that required improvement in order to improve pupils' academic achievements. Those who are aspiring to join the profession know most of the required teacher competencies. They observe what teachers do to them while in school. A reason to explain presence of untrained teachers in the profession. Goh [7] carried out a study on conception of beginning teachers on the required teacher competencies in Malaysia. The study revealed that beginning teachers in Malaysia were aware of subject and pedagogical knowledge, professional values as well as aspect of collaboration as the required teacher competencies. Unknown to beginning teachers was assessment competency. The current study explored competencies of professionally qualified, practicing teachers including assessment competencies. Salwa [29] observed that few teachers in Malaysia had been formally trained in the basic principles of measurement and teachers were lacking interpretation skills of nominal data and standardization of test instruments. Assessment for learning is an ongoing process where teacher uses an exploratory tool to monitor the progress of an individual learner in meeting a representative number of outcomes in subject or learning area. Salwa identified the issues with regard to teacher assessment competency in classroom as training in mastery of assessment guidelines, standardization of assessment, list of lacking skills among teachers in assessment and lacking skills among Islamic teachers in assessment. Islamic teachers required proficiency in Arabic language to be able to teach Islamic subjects. The study revealed that majority of Islamic education teachers had moderate level of proficiency and lower levels mastery in Arabic vocabulary. This was a secondary research, which relied on other people's findings. The current study was a primary research; all variables in assessment were included and level of teacher assessment competency and its influence on pupils' academic achievement established.

Assessment of Pupils is done using various tools and arrangements. Government of Botswana has recognized that teacher competencies directly influence pupils' academic achievement [27]. One of the competencies recognized as essential is assessment. In recognition of teachers' assessment competency as having direct influence on pupils academic achievement, there was need to base teachers competency on a framework developed from set standards. The current study established teachers' assessment competency based on competency framework for primary school teachers' document. National policy on education in Nigeria clearly states that educational assessment and evaluation will be 
liberalized. This will be achieved by basing whole or part of the progress of individual students on continuous assessment (CA) [30]. It specified that primary school certificate be based on continuous assessment. Okpala and Onocha [31] stated that there had been problems with effective implementation of continuous assessment. This could be a result of assessment practices of teachers in relation to the population of students assessed. To this end, there were training and in-training programmes of teachers as part of continuous assessment implementation. The literature did not spell how CA was to be administered and therefore formative assessment practice in Nigeria was not clear. The current study attempted to fill this gap by determining formative assessment practice at school and county level.

Measurement and assessment is an essential element of teacher competencies. Few studies have been carried out on teacher competencies in educational assessment of students. However, one such study was by Omo-Egbekuse et al. [30], in Nigeria. The objective of the study was to find out the extent to which primary and junior secondary school teachers were competent in the seven standards for teacher competency in assessment of students and the differences in the level of competencies between the two groups. She used survey design employing questionnaire that was administered to teachers only. The areas looked at were Selecting assessment method, developing assessment methods, administering, scoring and interpreting results of assessment, use of assessment results in decisionmaking, use of assessment for grading, communicating assessment results and recognition of unethical practices. The results of the study revealed that the teachers who took part in the study had the required competency a part from ethical practices. This study took a macro level approach and left out very essential competencies; test specification and construction of test items. The current study took a micro level approach and in addition determined test specification and construction of test items competencies.

In order to evaluate students learning teachers normally carry out assessment of learning. This requires teachers' assessment competency. Adodo [32], conducted a study on teacher assessment competency in assessing students cognitive and psycho-motor achievement basic science teaching in secondary schools. The objective of the study was to assess the competency of basic science and technology teachers in evaluating the students' cognitive achievement. The hypothesis was that there is no significance difference in the teachers' qualification and their level of competency in evaluating students' cognitive achievement in basic science and technology. The study was born out of the fact that there was poor performance of students registered in basic science and the number of candidates was dropping. This was observed as professional inadequacy to be addressed.
Thus, the study sought out to assess assessment competency of science and technology teachers and its relationship with teacher qualification. The results revealed that higher education qualification did not have any effect on teacher assessment competency. The observed F-ratio was 0.8200 while the Table value was 2.13. Thus, the result was not significant at 0.05 level. This study looked at level of teachers' assessment competency in relation to academic qualification. The study left out the effects of teacher assessment competency on pupils' academic achievement which is very crucial in research of this nature. The current study filled this gap by establishing influence of teachers' assessment competency on pupils' academic achievement. Other study by Akinbode and Abati [33] reported that teaching methods, techniques and teaching practice contribute to the trainee teacher professional competency. Apart from the observed teacher competencies, assessment is an essential competency a teacher must possess. The present study established level of teachers' assessment competency.

Teachers need a tool to guide them on the required competencies in carrying out their duties. This ideally calls for competency framework. Uganda government has developed competency profile for primary school teachers [34]. The profile has been developed as a professional tool to guide teachers and all other the stakeholders in primary education in identifying the desired competencies of the primary school teachers in Uganda. The profile is to help stakeholders direct their efforts appropriately in their quest for teacher improvement. The team came up with Knowledge, Skills, Value and Attitude, Professional ethics competencies. Under knowledge competency, assessment of pupils learning is briefly mentioned. This falls short of test and measurement competency required by a teacher to develop a valid and reliable test instrument. Poro et al. [35] acknowledged that quality of education is measured by pupils' performance $n$ tests. This called for the need to establish teacher assessment competency and determine its influence on pupils academic achievement. This study failed to establish teachers' assessment competency and its influence on pupils' academic achievement. The present study filled this gap by establishing teachers' assessment competency level from a broad perspective and determining its influence on pupils academic achievement.

The 2.6.6.3 system of education introduced is based on the 2012 report of task force on the realignment of education sector to the Kenya vision 2030 and constitution of Kenya 2010. From this report, government developed sessional paper number 2 of 2015. The sessional paper recommended among others, a competency based curriculum and establishment of a national learning assessment [36]. The BECF recognizes the vital role of assessment as a tool of learning and means of establishing the extent to which 
the designed learning outcomes have been developed. The BECF provides an opportunity for redesigning assessment to ensure that it plays its rightful place in the education sector. The framework recognizes that assessment which is crucial for provision of quality education has been limited to summative assessment while majority of teachers hardly ever use formative assessment referred to as ongoing assessment or progress monitoring in education literature. A shift in assessment practices will be the adoption of CBA. The CBA will facilitate the use of formative assessment practices. The BECF recognizes the need to train teachers in the approved methods of collecting, recording, compiling and interpreting evidence of learners' growth and progress. Reforms in teacher education are complete. These reforms have been informed by the ongoing reforms in the basic education curriculum. The reforms in teacher education focused on early childhood development education, primary teacher education, diploma secondary teacher education, diploma special needs education and diploma technical and vocational education. It has been affirmed that teacher education will now be anchored on well stipulated standards that are accepted internationally [37] Assessment of competencies is criterion referenced assessment. The current curriculum is objective based and the assessment of objectives is norm referenced assessment. It would be important to carry out a research on teachers' assessment competencies in order to determine their strengths and weaknesses. This would enable Ministry of Education to be in an advantage position when redesigning assessment competencies for training programme required by teachers to be used in training and retraining. The current study attempted to fill this gap by determining teachers' knowledge on construction of multiple-choice test items, exploring organization of examination administration in schools and their competency level.
Administration of assignments to pupils is an important aspect of assessment and should be done in a professional manner in learning institution. Internal conditions of examination environment should not be of any difference to external ones. Study carried out by Kimani, Kara and Njagi [38] on teacher factors influencing students' academic achievement in secondary schools in Nyandarua County considered administration of students' assignment. The study revealed that there was statistically significant relationship between administration of students' assignment and students' academic achievement. The finding concurred with Kapambwe [39] who opines that use of continuous assignment test had a powerful impact on students' academic achievement. Kimani et al. [38] study only looked at administration of assignment to pupils. A part from administration of assignment, the current study determined teachers' competency level in construction of test items, choice of assessment method and interpretation of assessment results.

\section{RESEARCH METHODOLOGY}

This study used survey research design. Survey design aims at describing the characteristics of a population by examining a sample of that group [40]. This design was suitable because the study was set to determine teachers' professional competencies influence on pupils' academic achievements by administering questionnaire to teachers' samples. The study population comprised 3290 teachers of standard eight of the year 2018, 658 head teachers, 7 Assistant Deputy Directors Teacher Management (ADDTMs) [41] and 7 Education Quality and Assurance Standards Officers (QASOs) in Kisumu County [41]. In this study, Saunders, Philip and Thornbill [42] table developed for determining small sample size needed to be a representative of a given population was used to select sample size of teachers and head teachers of mixed schools.

The sample frame is shown in Table 2.

Table-2: Sample Frame

\begin{tabular}{|r|l|l|l|r|}
\hline Category & Population & Selected Sample & Percentage & Sampling Technique \\
\hline Teachers & 3290 & 322 & \multicolumn{2}{|c|}{ Saunders et al. table } \\
\hline Head Teacher-mixed & 655 & 217 & & Saunders et al. table \\
\hline Head Teachers-Girls & 2 & 2 & 100 & Purposive \\
\hline Head Teachers-boys & 1 & 1 & 100 & Purposive \\
\hline QASOs & 7 & 7 & 100 & Purposive \\
\hline ADDTMs & 7 & 7 & 100 & Purposive \\
\hline TOTAL & $\mathbf{3 , 9 6 2}$ & $\mathbf{5 5 6}$ & & \\
\hline
\end{tabular}

Table 2 shows categories of the respondents, population, and sample size. Percentage selected and sampling technique. Saunders, Philip and Thornbill [43] table was used for determining sample size of teachers and head teachers of mixed schools as they were a large population and the researcher required small size sample. The head teachers for girls and boys schools, the ADDTMs were few hence sampled purposively. Data was collected using interview schedules, questionnaires and observation checklist. 


\section{FINDINGS}

\section{Influence of Teachers' Assessment Competency on} Pupils' Academic Achievement

The study sought to determine influence of teachers' assessment competency on pupils' academic achievement. Data was collected using teachers' questionnaire. Five items on assessment were generated from Kenya primary school teachers' competency framework document which comprised designing appropriate, valid and reliable assessment tools and using them appropriately for the intended purpose were employed. The items were guided by assessment competency indicators shown in Table 3. The items covered were: Assessment method; construction of objective test items; determining number of questions, qualities and characteristics a test should have prior to its construction; organization of examination administration; test scores for interpretation of examination results and period for feedback from assessment tools. Feedback is a core component of formative assessment. Teachers were asked to respond to these questions. The intention was to establish teachers' formal assessment competency level. Assessment competency levels were established using teacher competency rating scale shown in Table 3 . The findings of teachers' assessment competency level and KCPE mean scores were as shown in Table 3.

Table-3: Teachers' Assessment Competency Level and KCPE Mean

\begin{tabular}{|r|l|l|l|l|l|l|}
\hline $\begin{array}{c}\text { Assessment } \\
\text { competency } \\
\text { level }\end{array}$ & $\begin{array}{c}\text { KCPE } \\
\text { Mean }\end{array}$ & \multicolumn{1}{|c|}{$\mathbf{N}$} & $\begin{array}{c}\text { Std. } \\
\text { Deviation }\end{array}$ & $\begin{array}{c}\text { \% of } \\
\text { Total N }\end{array}$ & Minimum & Maximum \\
\hline $\begin{array}{r}\text { Weak } \\
\text { Competency }\end{array}$ & 259.3736 & 23 & 23.37591 & $8.0 \%$ & 206.11 & 325.67 \\
\hline $\begin{array}{r}\text { Average } \\
\text { Competency }\end{array}$ & 260.2226 & 86 & 33.24498 & $29.3 \%$ & 179.13 & 346.00 \\
\hline $\begin{array}{r}\text { Good } \\
\text { Competency }\end{array}$ & 268.4246 & 122 & 40.66361 & $41.5 \%$ & 188.08 & 375.00 \\
\hline $\begin{array}{r}\text { Very good } \\
\text { Competency }\end{array}$ & 269.4794 & 60 & 39.22160 & $20.3 \%$ & 188.08 & 375.00 \\
\hline $\begin{array}{r}\text { Excellent } \\
\text { Competency }\end{array}$ & 322.0667 & 3 & 54.45928 & $1.0 \%$ & 266.20 & 375.00 \\
\hline Total & $\mathbf{2 6 6 . 0 2 8 2}$ & $\mathbf{2 9 4}$ & $\mathbf{3 7 . 7 0 1 3 5}$ & $\mathbf{1 0 0 . 0 \%}$ & $\mathbf{1 7 9 . 1 3}$ & $\mathbf{3 7 5 . 0 0}$ \\
\hline
\end{tabular}

Note: Based on teacher competency rating scale adopted from national institute of health

From Table 3 it can be observed that teachers' assessment competency level ranged from weak to excellent competency. A large number $(109,37.3 \%)$ of teachers had weak to average assessment competency and only a meager number $(3,1.0 \%)$ of teachers had excellent assessment competency. This scenario is of great concern as observed by Gregory [21] who stated that there was a serious problem with educators as they lacked fundamental skills of assessment. Teachers with weak assessment competency obtained KCPE mean score of 259.37 with a minimum of 206.11 and maximum of 325.67. Those with average assessment competency obtained a mean of 260.22 mean score with a minimum of 179.13 and maximum of 346.00 while teachers of good and very good assessment competency obtained mean of 268.43 and 269.48 mean scores respectively with minimum of 188.08 and maximum of 375.00 for both. Teachers with excellent assessment competency obtained a mean of 322.07 mean score with a minimum of 266.20 and maximum of 375.00 . KCPE mean score obtained by teachers of weak to excellent assessment competency ranged from 259.37 to 322.07 in ascending order as shown in Table 4.7. In Kenya primary schools, apart from insha-composition writing in Kiswahili language and English composition all other examination papers are assessed using objective tests comprising multiple choice questions. The multiple choice questions have stem, task, key and distractors [44]. Thus, it was important to find out teachers knowledge in construction of multiple choice questions. In that regard, one of the items in teachers' questionnaire was on procedure of constructing multiple-choice items test. Teachers' responses were computed converted into percentages and presented in a pie chart. A serious weakness was revealed from teachers' response to item on procedure of constructing multiple-choice items test. This is shown in figure 1 . 


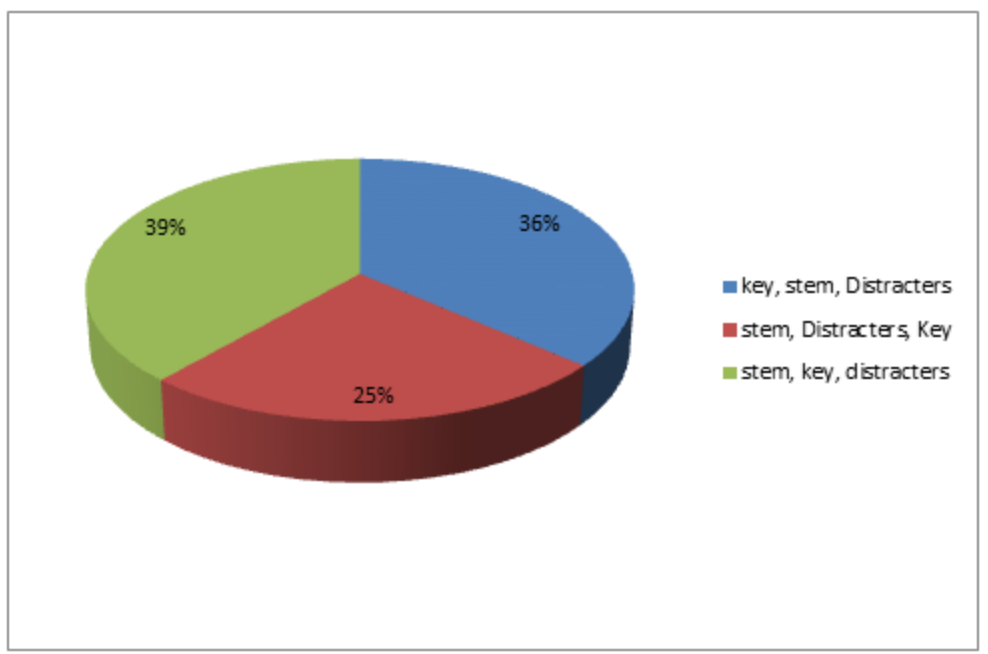

Fig-1: Teachers Knowledge on Construction of Multiple-choice Items Test

As shown in figure 1 it can be observed that $25 \%$ of teachers selected stem, distractors and key as the correct procedure of constructing multiple test items, $36.0 \%$ of selected key, stem and distractors. Both of these responses were irrelevant. Only $39.0 \%$ of teachers selected the correct response which was stem, key and distractors. This is a clear indication that a large $(179,61.0 \%)$ number teachers in primary schools in Kisumu County lack knowledge of constructing multiple test items which is a key component in assessment competency. This is attest to [21, 29] findings who contend that most educators lacked preparation skills in assessment.

Difference in KCPE mean score between teachers of weak assessment competency and average assessment competency was 0.849 , average assessment competency and good assessment competency was 8.202, good assessment competency and very good assessment competency was 1.0548, very good assessment competency and excellent competency was 52.59. This implied that pupils' academic achievement improved with increase in teachers' assessment competency level. This was an indication of linear relationship between teachers' assessment competency and pupils' academic achievement. Noted with concern was the difference between successive levels of teachers' assessment competency. For instance, difference in KCPE mean score between teachers of weak assessment competency and average assessment competency was a meagre 0.849 while difference between very good assessment competency and excellent competency was 52.59. The implication is that teacher's assessment competency level had great impact on pupils' academic achievement. This concurred with Keyworth et al. [19] findings who assert that teachers' assessment competency is a key to yielding great results. The study therefore tested the second hypothesis.

The following hypothesis was set.

$H_{01}$ There is no statistically significant relationship between teachers' assessment competency and pupils' academic achievement.

The correlation coefficient was determined using Pearson's product-moment correlations and generated using SPSS version 20. The results were as shown in Table 4.

Table-4: Relationship between Teachers' Assessment Competency and Pupils'Academic Achievement

\begin{tabular}{|l|l|r|r|}
\hline \multicolumn{2}{|c|}{} & $\begin{array}{c}\text { KCPE mean } \\
\text { score }\end{array}$ & $\begin{array}{c}\text { Percentage } \\
\text { Assessment } \\
\text { competency score }\end{array}$ \\
\hline \multirow{3}{*}{ KCPE mean score } & Pearson Correlation & 1 & $.121^{*}$ \\
\cline { 2 - 4 } & Sig. (2-tailed) & & .033 \\
\cline { 2 - 4 } & $\mathrm{N}$ & 294 & 294 \\
\hline \multirow{2}{*}{$\begin{array}{l}\text { Percentage Assessment } \\
\text { competency score }\end{array}$} & Pearson Correlation & $.121^{*}$ & 294 \\
\cline { 2 - 4 } & Sig. (2-tailed) & .033 & \\
\cline { 2 - 4 } & $\mathrm{N}$ & 294 & \\
\hline \multirow{2}{*}{$*$ Correlation is significant at the 0.05 level (2-tailed). } & & \\
\hline
\end{tabular}

As shown in Table 4 it can be observed that teacher assessment competency and pupils' academic achievement had a positive correlation $(0.121)$ and it was statistically significant as p-value $(0.033)<0.05$ level ( 2 tailed). Thus, the null hypothesis, there is no statistically significant relationship between teachers' assessment competency and pupils academic achievement was rejected and the alternative hypothesis 
that there was statistically significant relationship between teachers' assessment competency and pupils academic achievement was accepted. Value of correlations ' $r$ ' lies between +1 and -1 . The value of ' $r$ ' nearer +1 or -1 indicates strong correlations between the variables [45]. Thus a correlation of 0.121 is a strong positive correlation.

Findings from lesson observations showed that a small number $(12 ; 3.9 \%)$ of teachers were able to construct assessment items. However, the rest referred pupils to exercises from class textbook. Assessment should be an integral part of learning and therefore lesson plan should contain elements of assessment. Lesson observation revealed that teachers carried out assessment for learning through question-answer technique and did not incorporate assessment as learning in their teaching. Assessment as learning encourages pupils to take responsibility of their own learning. The implication is that in most schools teachers were not used to setting of examinations and relied on assessment of learning. This was demonstrated by the fact teachers relied only on class textbooks for pupils' exercises. A serious weakness in setting and production of examination papers was revealed by head teachers' admission that setting and production of examination papers internally was done only in 4 out of 203 schools. The remaining 199 schools bought examinations from printers and occasionally got ready papers from well-wishers especially for upper classes. This finding is similar to report of National Council on Measurement in Education [23] which states that teachers' assessment competency problem is traced to lack of exposure to assessment knowledge and most educators begin their career with a bumpy exposure to the fundamental of assessment. Now that the newly introduced 2-6-6-3 system of education is competency based where there is a shift from summative as the main assessment method to formative, this call for serious review of teachers' assessment competency in order for the system to meet its expectations.

From the findings, there was a statistically significant correlation between teachers' assessment competency and pupils' academic achievement. This concurred with findings of Kulshretha and Pandey [6] who recognized teachers' assessment competency as an important aspect of pupils academic achievement. In the current study, teachers of weak, average, good, very good, excellent knowledge competencies obtained a mean score of 259.4, 260.2, 268.4, 269.4 and 322.1 in KCPE respectively. From the foregone, it can be observed that level of teacher assessment competency has positive impact on pupils' academic achievement in primary schools. Thus, pupils' academic achievement in primary schools improves with the level of teachers' assessment competency.

\section{CONCLUSION}

Teachers who were not exposed to setting of examination papers were unable to effectively evaluate their pupils mastery of work covered in formal curriculum leading to pupils' low academic achievement. There is a strong positive relationship between teachers' assessment competency and pupils' academic achievement.

\section{RECOMMENDATIONS}

Kisumu County, director of education in conjunction with MOEST through Kenya Institute of Curriculum Development should organize regular inservice course on professional studies with emphasis on test and measurement skills. This would be in line with the newly introduced 2-6-6-3 system of education. The first 2 years pre-school, 3 years lower primary, 3 years upper primary, 3 years junior secondary, 3 years senior secondary and 3 years university education. This is a competency based curriculum and main assessment form is formative. Schools should pool their resources at base or zonal levels to enable them prepare and produce their own examinations. This would expose teachers to techniques of preparing examination there by acquiring assessment competency essential in evaluation of teaching and learning. Ministry of education should mount more in- services training for teachers to enable them develop effective assessment skills. Education programs should put more emphasis on assessment skills too.

\section{REFERENCES}

1. Lanier, J. T. (2014). Redefining the role of teacher: It's a multifaceted profession. Retrieved from http://www.edutopia.org/(3/4/2015)

2. Brick, J. M., \& Williams, D. (2013). Explaining rising nonresponse rates in cross-sectional surveys. The ANNALS of the American academy of political and social science, 645(1), 36-59.

3. University of Mexico. (2015). Nm teacher competencies. Retrieved from Teach nm.org/experienced teachers/nm-teacher competencies.html. (28/2/2015).

4. Department of Education and Training. (2014). Competency framework for teachers Australia. Retrieved from https://www.australia.gov.au.(20/4/2016)

5. General Teaching Council of Northern Ireland. (2006). Teaching: The reflexive profession. Retrieved from www.gtcn.org.uk/userfile/file/reflexive profession/3rd ed. pdf (22/10/2015)

6. Kulshretha, A. K., \& Pandey, K. (2013). Teacher training and professional competencies. Voice of Research Journal, 1(4), 29-31

7. Goh, P. S. C. (2013). Conceptions of competency: A Phenomenographic investigation of beginning teacher in Malaysia. The Qualities Report, 18(40) $1-6$ 
8. Jala, I. (2010, November $\left.1^{\text {st }}\right)$. The Crux of the Matter is Quality Education. The Malasyian Insider. Retrieved from http://www.themalysian insider.com/breakingnws/article/crux-of-thematter-is-quality-education-idris-jala/

9. Abdul, R., \& Abdul, G. (2010). Teacher competency testing among Malaysia school teachers. European Journal of Social Science, 12(4), 610-617

10. Ministry of Education. (2014). Primary school leaving examination. Retrieved from www.moe.gov.sg/Education/primary. ( 11/8/2014)

11. Nzilano, J. L. (2013). Pre-Service Teacher Competencies: The Experience of Practicing Teaching in Secondary Schools and Colleges. Africa Journal of Teacher Education, 3(1), 1-4

12. Mosha, M. A. (2014). Factors affecting students' performance in English language in zanzibar rural and urban secondary schools. Journal of Education and Practice, 5(35), 64-76

13. County Director of Education. (2019). Education and prize giving day, Kisumu County. Kisumu: Equity Bank

14. Kunter, M., Baumert, J., Voss, T., Klusman, U., Richter, D., \& Hachfeld A. (2013). Professional competence of teachers: Effects on instructional quality and student development. Journal of Educational Psychology, 105(3), 805-820

15. Kumar, M. S. (2013). The influence of teacher's professional competency on students' achievement. Journal of Engineering, 3(11), 12-18

16. Rakido, K.O., Kiplagat, P. \& Nyongesa, S. (2016). Influence of teachers competence on mathematics performance in KCSE examination among public schools in Nyatike Sub-County, Migori County. International Journal of Secondary Education 4950, 44-57

17. Sultan, S., \& Shafi, M. (2014). Impact of perceived teacher's competence on students' performance: Evidence for mediating/moderating role of class environment. Journal of I-Manager's journal on educational psychology, 7(1), 10-18

18. Nsw Government. (2019). Purpose of assessment. Retrieved from educationstandards.nsw. edu.au (11/9/2020)

19. Keyworth, R., Denrich, R., \& States, J. (2012). Introduction: Proceedings from Wing Institute's fifth annual summit on evidence Based Education at Crossroads. The State of Teacher Preparation. 2, ix-xxx. Oakland CA: The Wing.

20. Hattie, J. (2009). Visible learning: A synthesis of over 800 meta-analyses related to achievement. New York, NY: Routledge

21. Gregory, J. C. (2007). Formative classroom assessment and large scale assessment: implication for future research and development. In N.M.James (Ed). Formative assessment theory and practice. New York: Teachers College Press

22. Chiaramonte, P. (2015). California school backtracks on common core opt out punishment.
FoxNews.com. Retrieved from

www.foxnews.com/us/education/index.html

23. National Council on Measurement in Education. (2010). Competency standards in student assessment for administrators. Retrieved from http://buros.org/competency-standards-students

24. Gregory, E., \& Fatima, A. (2015). Rising expectations in Brazil and Chile. Education Next, 14(1), 5-12

25. Gullicson, J. R. (2010). Students' evaluation and their relationship to grade and curriculum. Journal of Educational Research, 79(80), 121-129

26. Bennet, D. (2014). “Alberta teacher's competency task force called direct assault".The Canadian Press. Retrieved from http://m.huffingtonpost.ca. $(2 / 5 / 2017)$

27. Ministry of Education. (2007). Curriculum development and evaluation programme implementation. Gabarone: Government Printers

28. Ministry of Education and Sports. (2014). Competency profile for primary school teachers. Retrieved from http://it/standards.pbworks.com $(3 / 2 / 2015)$

29. Salwa, S. (2013). Teachers assessment in classroom: Current issues. International Journal of Informative and Futuristic Reearch. 1(3), 90-96

30. Omo-Egbekuse, J. Omaze, A. \& Imobekhai (2013). Standards for teacher competency in educational assessment of students: Nigeria teachers `ratings of their need. Retrieved from www.iaea.info/documents/paper-2fb222b87.pdfq $(14 / 6 / 2017)$

31. Okpala, N.P., \& Onocha, C.O. (2007). Perceived needs and correlates of needs for improved evaluation practice of integrated science teachers. Benin Journal of Education, 3(2) 14-17

32. Adodo, S. S. (2014). An evaluation of secondary school teachers' competency in evaluating students' cognitive and psycho- motor achievement in basic science and technology. Journal of Emerging Trends in Education Research and Policy Studies (JETERAPS), 5(3), 48-53

33. Akinbode, O. S. \& Abati, O. A. (2019). Teacher preparation and teaching professional competence among federal colleges of education graduates in South West Nigeria. Journal of Education and Human Development, 8(1). 93-105

34. Ministry of Education Science and Technology. (2012). Primary school teacher competency framework. Retrieved from www.education.go.ke (17/4/2016)

35. Poro, S. G., Yiga, A. P., Enon, J. C., Fabian, M., \& Marus, E. (2019). Teacher competence and performance in primary schools in Nwoya District, Northern Uganda.

36. Machio, J. (2017a). Blow for Teachers Over free' KNEC workload. Retrieved from www.educationnews.co.ke (16/2/17) 
37. Machio, J. (2017b). New curriculum for ttc's set to launch. Retrieved from www.edcationnews.co.ke(15/8/17)

38. Kimani, G. N, Kara, A. J., \& Njagi, L. W. (2013). Teachers factors influencing students' academic achievement in Nyandarua County, Kenya. International Journal of Educational and Research, 1(3), 1-14.

39. Kapambwe, W. M. (2010). The implementation of school based continuous Assessment in Zambia. Education Research and Reviews, 5(3): 99-107.

40. Zoltan, D. (2007). Research Methods in Applied Linguistics: Qualitative, quantitative and Mixed Methods. New York: Oxford University Press.

41. County Director Teacher Management. (2019). Kisumu County primary schools teacher establishment 2018. Kisumu: CD-TCS Report.
42. Saunders, M., Lewis, p. \& Thornhill, A. (2009). Research methods for business students. $8^{\text {th }}$ edition. Routledge publishers. London

43. Sandra, C. (2009). A glimpse of secondary schools: Competencies and performance from a sample of teachers and students in Italy. Retrieved from www.sandrachristolini.it/wordpress/wpcontent. (28/2/15)

44. Brame, C. (2013). Writing multiple choice test questions. Retrieved from https:/cft.vanderbit.edu/guides-sub-pages/writinggood-multiple-choice-test-questions. (17/09/2020)

45. Kothari, C. R. (2004). Research methodology: Methods and techniques ( $2^{\text {nd }}$ ed). New Dehli: Age International Publishers. 